\title{
Fruits, vegetables and lung cancer: a pooled analysis of cohort studies
}

Citation for published version (APA):

Smith-Warner, S. A., Spiegelman, D., Yaun, S., Albanes, D., Beeson, W. L., van den Brandt, P. A., Feskanich, D., Folsom, A. R., Fraser, G. E., Freudenheim, J. L., Giovannucci, E., Goldbohm, R. A., Graham, S., Kushi, L. H., Miller, A. B., Pietinen, P., Rohan, T. E., Speizer, F. E., Willett, W. C., \& Hunter, D. J. (2003). Fruits, vegetables and lung cancer: a pooled analysis of cohort studies. International Journal of Cancer, 107(6), 1001-1011. https://doi.org/10.1002/ijc.11490

Document status and date:

Published: 01/01/2003

DOI:

10.1002/ijc. 11490

Document Version:

Publisher's PDF, also known as Version of record

\section{Please check the document version of this publication:}

- A submitted manuscript is the version of the article upon submission and before peer-review. There can be important differences between the submitted version and the official published version of record.

People interested in the research are advised to contact the author for the final version of the publication, or visit the DOI to the publisher's website.

- The final author version and the galley proof are versions of the publication after peer review.

- The final published version features the final layout of the paper including the volume, issue and page numbers.

Link to publication

\footnotetext{
General rights rights.

- You may freely distribute the URL identifying the publication in the public portal. please follow below link for the End User Agreement:

www.umlib.nl/taverne-license

Take down policy

If you believe that this document breaches copyright please contact us at:

repository@maastrichtuniversity.nl

providing details and we will investigate your claim.
}

Copyright and moral rights for the publications made accessible in the public portal are retained by the authors and/or other copyright owners and it is a condition of accessing publications that users recognise and abide by the legal requirements associated with these

- Users may download and print one copy of any publication from the public portal for the purpose of private study or research.

- You may not further distribute the material or use it for any profit-making activity or commercial gain

If the publication is distributed under the terms of Article $25 \mathrm{fa}$ of the Dutch Copyright Act, indicated by the "Taverne" license above, 


\section{FRUITS, VEGETABLES AND LUNG CANCER: A POOLED ANALYSIS OF COHORT STUDIES}

Stephanie A. Smith-WARner ${ }^{1 *}$, Donna SpIEGelman ${ }^{2,3}$, Shiaw-Shyuan Yaun $^{1}$, Demetrius Albanes ${ }^{4}$, W. Lawrence BeEson ${ }^{5}$, Piet A. van den Brandt ${ }^{6}$, Diane Feskanich ${ }^{7}$, Aaron R. Folsom ${ }^{8}$, Gary E. Fraser ${ }^{5}$, Jo L. Freudenheim ${ }^{9}$, Edward Giovannucci ${ }^{1,2,7}$, R. Alexandra Goldbohm ${ }^{10}$, Saxon Graham ${ }^{9}$, Lawrence H. Kushi ${ }^{11}$, Anthony B. Miller ${ }^{12}$, Pirjo Pietinen ${ }^{13}$, Thomas E. Rohan ${ }^{14}$, Frank E. SPEIZER ${ }^{7,15}$, Walter C. WILLETT ${ }^{1,2,7,16}$, and David J. HunTER ${ }^{1,2,7,16}$

${ }^{1}$ Department of Nutrition, Harvard School of Public Health, Boston, MA, USA

${ }^{2}$ Department of Epidemiology, Harvard School of Public Health, Boston, MA, USA

${ }^{3}$ Department of Biostatistics, Harvard School of Public Health, Boston, MA, USA

${ }^{4}$ Cancer Prevention Studies Branch, Division of Clinical Sciences, National Cancer Institute, Bethesda, MD, USA

${ }^{5}$ Center for Health Research, Loma Linda University School of Medicine, Loma Linda, CA, USA

${ }^{6}$ Department of Epidemiology, Maastricht University, Maastricht, The Netherlands

${ }^{7}$ Channing Laboratory, Department of Medicine, Brigham and Women's Hospital and Harvard Medical School, Boston, MA, USA

${ }^{8}$ Division of Epidemiology, School of Public Health, University of Minnesota, Minneapolis, MN, USA

${ }^{9}$ Department of Social and Preventive Medicine, University at Buffalo, State University of New York, Buffalo, NY, USA

${ }^{10}$ Department of Epidemiology, TNO Nutrition and Food Research Institute, Zeist, The Netherlands

${ }^{11}$ Division of Research, Kaiser Permanente, Oakland, CA, USA

${ }^{12}$ Department of Public Health Sciences, Faculty of Medicine, University of Toronto, Toronto, Ontario, Canada

${ }^{13}$ Department of Health Promotion and Epidemiology, National Public Health Institute, Helsinki, Finland

${ }^{14}$ Department of Epidemiology and Population Health, Albert Einstein College of Medicine, Bronx, NY, USA

${ }^{15}$ Department of Environmental Health, Harvard School of Public Health, Boston, MA, USA

${ }^{16}$ Harvard Center for Cancer Prevention, Boston, MA, USA

Inverse associations between fruit and vegetable consumption and lung cancer risk have been consistently reported. However, identifying the specific fruits and vegetables associated with lung cancer is difficult because the food groups and foods evaluated have varied across studies. We analyzed fruit and vegetable groups using standardized exposure and covariate definitions in 8 prospective studies. We combined study-specific relative risks (RRs) using a random effects model. In the pooled database, 3,206 incident lung cancer cases occurred among 430,281 women and men followed for up to 6-16 years across studies. Controlling for smoking habits and other lung cancer risk factors, a $16-23 \%$ reduction in lung cancer risk was observed for quintiles 2 through 5 vs. the lowest quintile of consumption for total fruits $(\mathbf{R R}=\mathbf{0 . 7 7}$; $95 \% \mathrm{Cl}=0.67-0.87$ for quintile 5; $p$-value, test for trend < $0.001)$ and for total fruits and vegetables $(R R=0.79 ; 95 \%$ $\mathrm{Cl}=0.69-0.90 ; p$-value, test for trend $=0.00 \mathrm{I})$. For the same comparison, the association was weaker for total vegetable consumption $(R R=0.88 ; 95 \% \mathrm{Cl}=0.78-1.00 ; p$-value, test for trend =0.12). Associations were similar between never, past, and current smokers. These results suggest that elevated fruit and vegetable consumption is associated with a modest reduction in lung cancer risk, which is mostly attributable to fruit, not vegetable, intake. However, we cannot rule out the possibility that our results are due to residual confounding by smoking. The primary focus for reducing lung cancer incidence should continue to be smoking prevention and cessation.

(C) 2003 Wiley-Liss, Inc.

Key words: fruit; vegetables; lung neoplasms; cohort studies; pooling

Lung cancer is the most common cancer in the world. ${ }^{1}$ Although cigarette smoking is the primary cause of lung cancer, ${ }^{2-4}$ other factors, such as diet, have been hypothesized to influence lung cancer risk. Observational studies, mainly using a case-control design, have consistently shown an inverse association between fruit and vegetable intake and lung cancer risk. ${ }^{5-7}$ However, because fruits and vegetables are heterogeneous with respect to phytochemical content and culinary usage,${ }^{8-11}$ associations with lung cancer risk may differ between groups of fruits and vegetables. Evaluation of the published literature for specific groups of fruits and vegetables is difficult due to the considerable variation in the food groups reported. In addition, investigators may tend to report results that are statistically significant, leading to publication bias. Therefore, we evaluated associations between specific and overall fruit and vegetable intakes and the risk of lung cancer in the Pooling Project of Prospective Studies of Diet and Cancer (Pooling Project). Using the primary data from each of the cohort studies, we standardized definitions of fruit and vegetable categories and covariates across studies and evaluated associations by smoking status and histologic type.

\section{MATERIAL AND METHODS}

The Pooling Project has been described previously. ${ }^{12}$ For the lung cancer analyses, we identified 8 prospective studies ${ }^{13-19}$ that met the following predefined criteria: at least 50 incident lung cancer cases; assessment of usual diet; conduct of a validation study of the diet assessment method or a closely related instrument; and assessment of smoking habits (Table I). Because most studies included only one sex, studies including women and men were analyzed as 2 separate cohorts. The person-time experienced during follow-up of the Nurses' Health Study (NHS) was divided into 2 asymptotically uncorrelated segments (NHSa, NHSb) for analysis to take advantage of the more detailed dietary assessment completed 6 years after baseline. According to the theory of survival data analysis, blocks of person-time in different time periods are asymptotically uncorrelated, regardless of the extent to which they are derived from the same people. ${ }^{20}$ So, pooling

Grant sponsor: the National Institutes of Health; Grant number: CA55075, CA78548.

*Correspondence to: Harvard School of Public Health, Department of Nutrition, 665 Huntington Avenue, Boston, MA 02115.

Fax: +617-432-2435.

Received 24 March 2003; Revised 25 June 2003; Accepted 8 July 2003

DOI 10.1002/ijc.11490 
TABLE I - CHARACTERISTICS OF THE PROSPECTIVE COHORT STUDIES INCLUDED IN THE POOLED ANALYSIS OF FRUIT AND VEGETABLE INTAKE AND LUNG CANCER

\begin{tabular}{|c|c|c|c|c|c|c|c|c|c|}
\hline \multirow[b]{2}{*}{ Study } & \multirow{2}{*}{$\begin{array}{l}\text { Years of } \\
\text { follow-up }\end{array}$} & \multirow[b]{2}{*}{ Sex } & \multirow{2}{*}{$\begin{array}{l}\text { Baseline } \\
\text { cohort }\end{array}$} & \multirow{2}{*}{$\begin{array}{l}\% \text { current } \\
\text { smokers }\end{array}$} & \multirow{2}{*}{$\begin{array}{l}\text { Number of } \\
\text { cases }\end{array}$} & \multicolumn{2}{|c|}{ Total fruits } & \multicolumn{2}{|c|}{ Total vegetables } \\
\hline & & & & & & $\begin{array}{l}\text { No. of } \\
\text { items }\end{array}$ & $\begin{array}{l}\text { Median intake } \\
(10-90 \%) \text { g/day }\end{array}$ & $\begin{array}{c}\text { Number of } \\
\text { items }\end{array}$ & $\begin{array}{l}\text { Median intake } \\
(10-90 \%) \text { g/day }\end{array}$ \\
\hline \multirow{2}{*}{ Adventist Health Study } & 1976-1982 & W & 17,990 & 2 & 20 & 7 & $354(133-652)$ & 6 & $162(74-269)$ \\
\hline & & M & 12,526 & 6 & 31 & 7 & $310(104-604)$ & 6 & $151(63-251)$ \\
\hline $\begin{array}{l}\text { Alpha-Tocopherol Beta Carotene } \\
\text { Cancer Prevention Study }\end{array}$ & 1985-1996 & M & $6,771^{\mathrm{a}}$ & 100 & 298 & 26 & $121(28-299)$ & 38 & $94(36-198)$ \\
\hline $\begin{array}{l}\text { Canadian National Breast } \\
\text { Screening Study }\end{array}$ & 1980-1993 & $\mathrm{W}$ & 56,837 & 20 & 149 & 6 & $314(110-578)$ & 15 & $221(101-438)$ \\
\hline $\begin{array}{l}\text { Health Professionals Follow-Up } \\
\text { Study }\end{array}$ & 1986-1996 & M & 44,350 & 9 & 244 & 15 & $300(98-621)$ & 28 & $293(141-550)$ \\
\hline Iowa Women's Health Study & 1986-1996 & $\mathrm{W}$ & 33,828 & 15 & 433 & 15 & $339(131-624)$ & 31 & $195(92-383)$ \\
\hline \multirow[t]{2}{*}{ Netherlands Cohort Study } & 1986-1992 & $\mathrm{W}$ & 62,412 & 20 & 131 & 12 & $207(83-389)$ & 25 & $164(89-295)$ \\
\hline & & $\mathrm{M}$ & 58,279 & 33 & 843 & 12 & $155(47-331)$ & 25 & $157(85-276)$ \\
\hline \multirow[t]{2}{*}{ New York State Cohort } & 1980-1987 & $\mathrm{W}$ & 21,045 & 23 & 130 & 8 & $290(87-539)$ & 23 & $188(72-363)$ \\
\hline & & M & 27,936 & 21 & 392 & 8 & $258(71-492)$ & 23 & $186(76-341)$ \\
\hline Nurses' Health Study a & 1980-1986 & $\mathrm{W}$ & 88,307 & 29 & 156 & 6 & $272(73-560)$ & 13 & $150(68-292)$ \\
\hline Nurses' Health Study b & 1986-1996 & $\mathrm{W}$ & $68,307^{\mathrm{b}}$ & 21 & 379 & 21 & $329(116-642)$ & 33 & $259(129-470)$ \\
\hline Total & & & 430,281 & & 3,206 & & & & \\
\hline
\end{tabular}

${ }^{\mathrm{a}}$ Only the placebo group of the Alpha-Tocopherol Beta Carotene Cancer Prevention Study is included in this analysis. $-{ }^{\mathrm{b}}$ The participants in the baseline cohort for the Nurses' Health Study b are included in the Nurses' Health Study a and are not included in the total.--For context, 1 medium orange weighs $121 \mathrm{~g}, 6$ ounces of orange juice weighs $187 \mathrm{~g}$, and $1 / 2$ cup cooked carrots weights $78 \mathrm{~g}$.

estimates from these 2 time periods is a statistically valid alternative to using a single time period.

\section{Dietary assessment}

Diet was measured at baseline in each study using a food frequency questionnaire designed for that particular study. The number of fruit and vegetable questions ranged from 9 in the Sweden Mammography Cohort to 54 in the NHSb. Food group intakes were calculated by adding the intake data for the specific foods included in that food group that were listed on the study's food frequency questionnaire. We examined associations with fruits and fruit juice (total fruits); vegetables and vegetable juice (total vegetables); and fruits, vegetables and juice (total fruits and vegetables). Potatoes and mature beans were not classified as vegetables because of their high starch and protein content, respectively. ${ }^{21}$ Associations also were examined for specific fruits and vegetables for which intakes were assessed as separate food items in over half the studies. The food frequency questionnaires from some studies collapsed multiple foods on a single line (e.g., apples and pears); thus, in some cases, the results for multiple foods are presented together.

Validation studies $22-29$ have been conducted for the food frequency questionnaires used in each cohort study in the Pooling Project or a closely related instrument. For vitamin C intake, a nutrient concentrated in fruits and vegetables, Spearman correlation coefficients between intakes from the food frequency questionnaire and the reference method generally ranged from 0.4 to 0.7 across the studies. Of the studies included in these analyses, only the Netherlands Cohort Study ${ }^{27}$ and Alpha Tocopherol BetaCarotene Cancer Prevention Study ${ }^{23}$ have evaluated the validity of total fruits (Spearman correlation coefficients $=0.60$ and 0.69 , respectively) and total vegetables (Spearman correlation coefficients $=0.38$ and 0.58 , respectively) as a group. In the Nurses' Health Study ${ }^{30}$ and Health Professionals Follow-Up Study, ${ }^{31}$ correlations for total fruits and total vegetables were not evaluated; however, the median correlations comparing intakes of individual fruits and vegetables estimated from the food frequency questionnaire with those from multiple dietary records were approximately 0.3 .

\section{Assessment of nondietary risk factors}

Information on potential nondietary risk factors was collected at baseline in each study using self-administered questionnaires designed for that particular study. For smoking history, each study assessed whether individuals had ever smoked or were current smokers. Among smokers, the number of cigarettes smoked per day and the years smoked were assessed.

\section{Identification of lung cancer outcomes}

Each study ascertained incident lung cancers using follow-up questionnaires with subsequent medical record review ${ }^{13,16,32}$ and/or linkage with a cancer registry. ${ }^{14-16,18,19,32}$ In addition, some studies used mortality registries or death certificates. ${ }^{13,18,19,32} \mathrm{We}$ categorized lung cancers based on the International Classification of Diseases for Oncology morphology $\operatorname{codes}^{33}$ or the histologic classification provided by the original study investigators.

\section{Statistical analysis}

For each data set, after applying the exclusion criteria used by that study, we excluded participants if they reported energy intakes greater or less than 3 standard deviations from the study-specific $\log _{\mathrm{e}}$-transformed mean energy intake of the baseline population, reported a history of cancer (except nonmelanoma skin cancer) at baseline or were missing information on smoking habits.

Each study was analyzed using the Cox proportional hazards model. The Canadian National Breast Screening Study and Netherlands Cohort Study were analyzed as case-cohort studies ${ }^{34}$ using Epicure software. ${ }^{35}$ The remaining studies were analyzed using SAS PROC PHREG. ${ }^{36}$ Person-years of follow-up were calculated from the date of the baseline questionnaire until the date of lung cancer diagnosis, death or end of follow-up, whichever came first. Age at baseline and the year the baseline questionnaire was returned were included as stratification variables. The proportion of missing values for each covariate was $<7 \%$ in each study; in the multivariate analyses, an indicator variable for missing responses was created for covariates, if applicable. Two-sided 95\% confidence intervals and $p$-values were calculated. We calculated summary relative risks using the random effects model. ${ }^{37}$ The studyspecific $\log _{\mathrm{e}}$ relative risks were weighted by the inverse of their variance. We tested for heterogeneity among studies using the Q-statistic. ${ }^{37,38}$

We analyzed associations of risk with total fruits, total vegetables and total fruits and vegetables according to quintiles of consumption. Study-specific quintiles were assigned based on the distributions in the subcohort in the case-cohort studies and in the baseline cohort for the remaining studies. We also analyzed associations for these groups using cutpoints based on identical absolute intakes across studies; the Adventist Health Study was excluded from these analyses because there were few cases in this study. To calculate the $p$-value for the test for trend across cate- 
gories of intake, participants were assigned the median value of their category and this variable was entered as a continuous term in the regression model.

Using a metaregression model, ${ }^{39}$ we tested for variation in relative risks by sex, the number of fruit and vegetable questions included on the food frequency questionnaire and smoking status. We also tested whether associations differed between adenocarcinomas, small cell carcinomas and squamous cell carcinomas using a 2 degree of freedom-squared Wald test statistic. ${ }^{40}$ Collectively, these 3 histologic types represented at least $60 \%$ of the cases in each study.

\section{RESULTS}

In the 8 studies in this analysis, 3,206 lung cancer cases $(1,398$ women, 1,808 men) occurred among over 280,419 women and 149,862 men (Table I). There were 280 cases among never smokers, 1,004 among past smokers and 1,922 among current smokers. Fruit consumption was highest among never smokers and lowest among current smokers. For vegetables, intakes among never and past smokers generally were similar and exceeded intakes among current smokers (Table II).

In the age-adjusted analyses, lung cancer risk was reduced by $29-56 \%$ for comparisons of the highest $v s$. lowest quintile of total fruit, total vegetable and total fruit and vegetable intakes (Table III). Adjustment for education, body mass index, alcohol intake and energy intake did not materially change the relative risks (results not shown). The associations were substantially attenuated after additional adjustment for smoking status (multivariate 1, Table III). Further attenuation occurred when duration of smoking and the amount smoked were included in the model (mulitvariate 2, Table III). Similar associations were observed for quintiles 2 through 5 relative to quintile 1. For comparisons of the highest $v s$. lowest quintile of intake, the pooled multivariate relative risks were $0.77(95 \% \mathrm{CI}=0.67-0.87)$ for total fruits (Fig. 1) and 0.88 $(95 \% \mathrm{CI}=0.78-1.00)$ for total vegetables (Fig. 2). The test for heterogeneity among studies was not significant for total fruits, total vegetables or total fruits and vegetables, indicating that the differences in relative risks across the studies were compatible with random variation. No associations were significantly modified by sex, although associations tended to be stronger and statistically significant among men compared to women. There was no evidence of effect modification by the number of fruit and vegetable questions included on a study's food frequency questionnaire ( $p$-value $=0.98$ for total fruits, 0.44 for total vegetables, 0.74 for total fruits and vegetables). Similar patterns in relative risks were observed when we excluded cases who died within 1 year of diagnosis (number of cases in analysis $=1,472$; results not shown) and when we stratified the cases by age at diagnosis. For lung cancers identified in individuals younger than 65 years, the pooled multivariate relative risks $(95 \% \mathrm{CI})$ comparing the highest vs. lowest quartile were $0.83(0.69-1.00)$ for total fruits, $0.75(0.63-$ $0.89)$ for total vegetables and $0.74(0.62-0.89)$ for total fruits and vegetables. For lung cancers identified in individuals 65 years and older, the corresponding relative risks were $0.72(0.60-0.87)$ for total fruits, $1.09(0.86-1.38)$ for total vegetables and $0.85(0.70-$ 1.03) for total fruits and vegetables. Results were similar after further adjustment for multivitamin use (results not shown). Simultaneous adjustment for total fruit and total vegetable intakes (results not shown) did not materially alter the results observed when each group was analyzed separately. Models that controlled for smoking using a 10-level variable accounting for smoking status, amount smoked and years smoked or that controlled for smoking pack-years each yielded relative risks for the dietary variables intermediate between those observed for the model adjusting for smoking status only (multivariate 1, Table III) and the model adjusting for smoking status, duration of smoking and amount smoked (multivariate 2, Table III). Results from models that included a squared term for duration of smoking in addition to smoking status, duration of smoking and amount smoked were unchanged from those presented for the multivariate 2 model in Table III.

When we categorized fruit and vegetable intakes into deciles, the pooled multivariate relative risks for the highest $v \mathrm{~s}$. lowest decile of intake were $0.68(95 \% \mathrm{CI}=0.56-0.83)$ for total fruits, $0.89(95 \% \mathrm{CI}=0.75-1.06)$ for total vegetables and $0.74(95 \%$ $\mathrm{CI}=0.62-0.89)$ for total fruits and vegetables. Similar relative risks were observed for the quintile and decile analyses after excluding cases diagnosed during the first 2 years of follow-up (results not shown).

When total fruit and total vegetable intakes were analyzed as categories defined using identical absolute intake cutpoints across studies, the pooled multivariate relative risks were $0.82(95 \% \mathrm{CI}=$ $0.68-0.98)$ for total fruits and $0.90(95 \% \mathrm{CI}=0.71-1.12)$ for total vegetables for comparisons of intakes of $\geq 400 \mathrm{vs}$. $<100 \mathrm{~g} /$ day (Fig. 3). For total fruits and vegetables, the pooled multivariate relative risks for comparisons of intakes of $\geq 600 \mathrm{vs}$. $<200 \mathrm{~g} / \mathrm{day}$ were $0.76(95 \% \mathrm{CI}=0.63-0.91 ; p$-value, test for between-study heterogeneity $=0.38 ; p$-value, test for between-study heterogeneity due to $\operatorname{sex}=0.10)$.

TABLE II - AGE-ADJUSTED MEAN FRUIT AND VEGETABLE INTAKES (g/DAY) BY SMOKING STATUS

\begin{tabular}{|c|c|c|c|c|c|c|c|c|c|}
\hline \multirow{3}{*}{ Study } & \multicolumn{3}{|c|}{ Never smokers } & \multicolumn{3}{|c|}{ Past smokers } & \multicolumn{3}{|c|}{ Current smokers } \\
\hline & \multirow{2}{*}{$\begin{array}{l}\text { Number of } \\
\text { participants }\end{array}$} & \multicolumn{2}{|c|}{ Mean intakes (g/day) } & \multirow[b]{2}{*}{$\begin{array}{l}\text { Number of } \\
\text { participants }\end{array}$} & \multicolumn{2}{|c|}{ Mean intakes (g/day) } & \multirow{2}{*}{$\begin{array}{l}\text { Number of } \\
\text { participants }\end{array}$} & \multicolumn{2}{|c|}{ Mean intakes (g/day) } \\
\hline & & Total fruits & $\begin{array}{c}\text { Total } \\
\text { vegetables }\end{array}$ & & Total fruits & $\begin{array}{c}\text { Total } \\
\text { vegetables }\end{array}$ & & Total fruits & $\begin{array}{c}\text { Total } \\
\text { vegetables }\end{array}$ \\
\hline Adventist Health Study (W) & 15,214 & 385 & 170 & 2,442 & 356 & 165 & 334 & 285 & 153 \\
\hline Adventist Health Study (M) & 7,764 & 359 & 161 & 4,020 & 325 & 154 & 742 & 220 & 132 \\
\hline $\begin{array}{l}\text { Alpha Tocopherol Beta-Carotene } \\
\text { Cancer Prevention Study }\end{array}$ & & & & & & & 6,771 & 149 & 109 \\
\hline $\begin{array}{l}\text { Canadian National Breast Screening } \\
\text { Study }^{\mathrm{b}}\end{array}$ & 2,688 & 353 & 246 & 1,462 & 348 & 267 & 1,064 & 287 & 245 \\
\hline $\begin{array}{l}\text { Health Professionals Follow-Up } \\
\text { Study }\end{array}$ & 21,274 & 368 & 330 & 18,922 & 334 & 330 & 4,140 & 265 & 301 \\
\hline Iowa Women's Health Study & 22,399 & 388 & 226 & 6,456 & 361 & 233 & 4,969 & 298 & 210 \\
\hline Netherlands Cohort Study (W) ${ }^{\mathbf{b}}$ & 941 & 239 & 181 & 309 & 219 & 184 & 311 & 201 & 178 \\
\hline Netherlands Cohort Study $(\mathrm{M})^{\mathrm{b}}$ & 202 & 211 & 170 & 753 & 187 & 175 & 478 & 154 & 169 \\
\hline New York State Cohort (W) & 10,773 & 322 & 208 & 5,448 & 322 & 217 & 4,824 & 261 & 193 \\
\hline New York State Cohort (M) & 8,458 & 304 & 205 & 13,666 & 279 & 205 & 5,812 & 223 & 182 \\
\hline Nurses' Health Study a & 38,469 & 328 & 171 & 24,467 & 321 & 178 & 25,358 & 261 & 165 \\
\hline Nurses' Health Study b & 30,166 & 388 & 285 & 23,820 & 368 & 298 & 14,309 & 307 & 268 \\
\hline
\end{tabular}

${ }^{\mathrm{a}}$ The Alpha Tocopherol Beta-Carotene Cancer Prevention Study only includes current smokers. $-{ }^{\mathrm{b}}$ Only data for the subcohort were used to calculate mean intakes. 


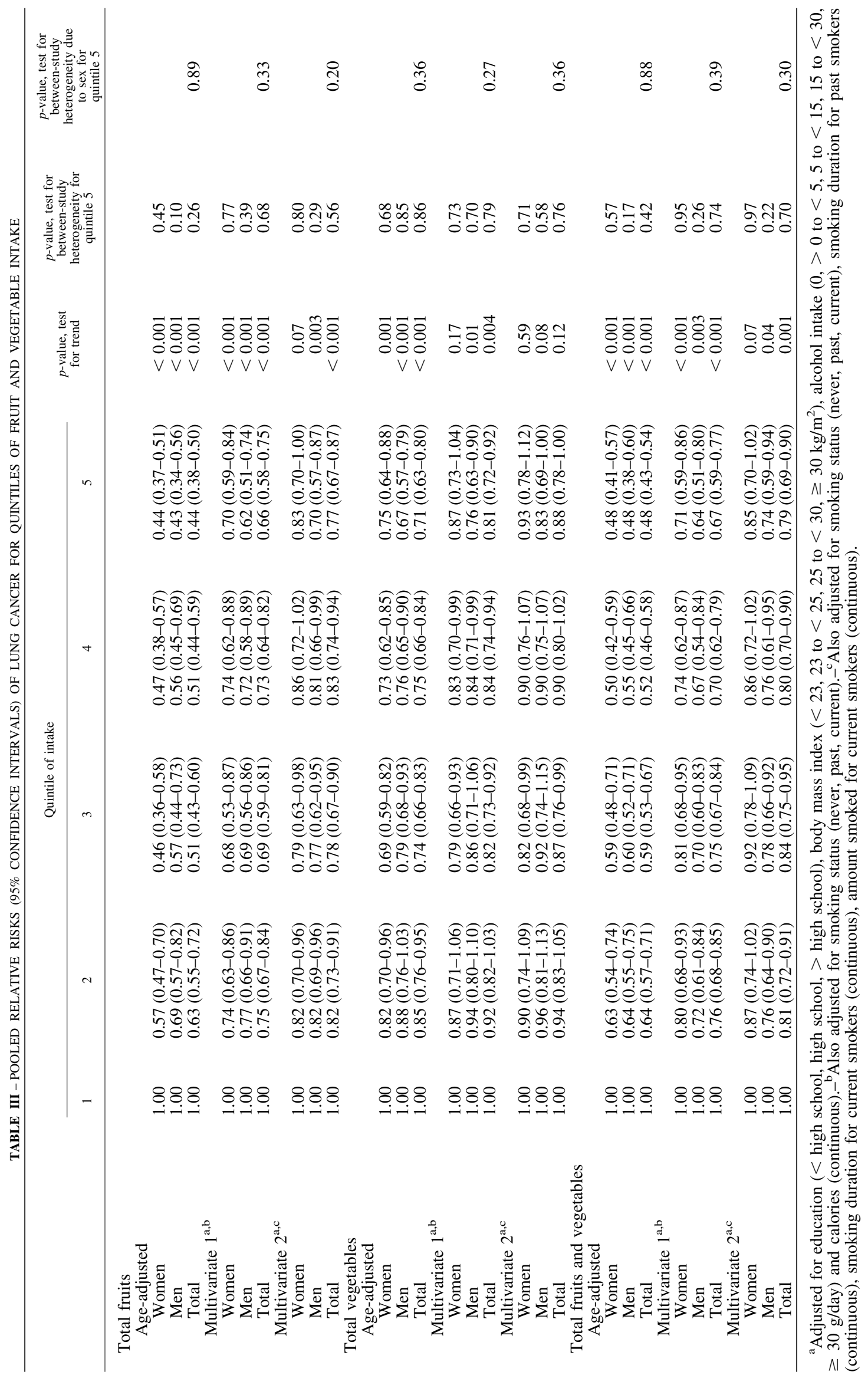




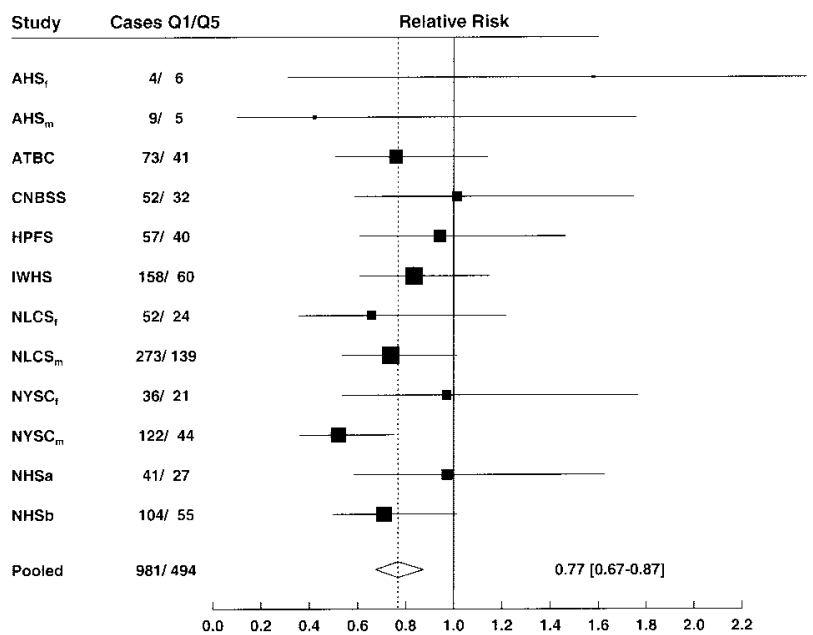

Figure 1 - Study-specific and pooled multivariate-adjusted relative risks of lung cancer and total fruit consumption, quintile $5 v s$. quintile 1. The black squares and horizontal lines correspond to the studyspecific relative risks and $95 \%$ confidence intervals for the comparison of quintile 5 to quintile 1 of total fruit consumption. The area of the black squares reflects the study-specific weight (inverse of the variance). The diamond represents the pooled relative risk and 95\% confidence interval. $\mathrm{AHS}_{\mathrm{f}}$, female cohort of the Adventist Health Study; $\mathrm{AHS}_{\mathrm{m}}$, male cohort of the Adventist Health Study; ATBC, Alpha-Tocopherol Beta-Carotene Cancer Prevention Study; CNBSS, Canadian National Breast Screening Study; HPFS, Health Professionals Follow-Up Study; IWHS, Iowa Women's Health Study; NLCS female cohort of the Netherlands Cohort Study; $\mathrm{NLCS}_{\mathrm{m}}$, male cohort of the Netherlands Cohort Study; NYSC , female cohort of the New York State Cohort; $\mathrm{NYSC}_{\mathrm{m}}$, male cohort of the New York State Cohort; NHSa, Nurses' Health Study a; NHSb, Nurses' Health Study b.

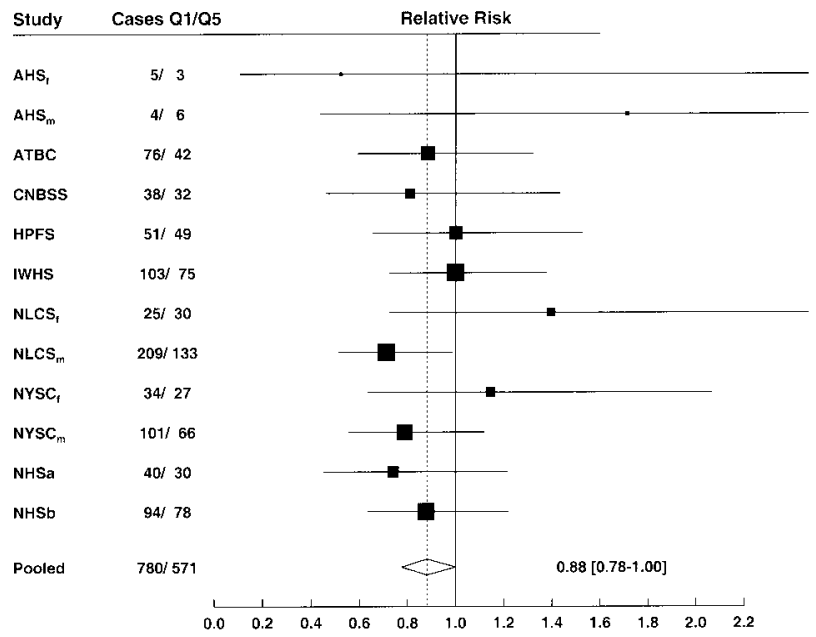

Figure 2 - Study-specific and pooled multivariate-adjusted relative risks of lung cancer and total vegetable consumption, quintile $5 \mathrm{vs}$. quintile 1 . The black squares and horizontal lines correspond to the study-specific relative risks and 95\% confidence intervals for the comparison of quintile 5 to 1 of total vegetable consumption. The area of the black squares reflects the study-specific weight (inverse of the variance). The diamond represents the pooled relative risk and $95 \%$ confidence interval. See legend to Figure 1 for abbreviations.

\section{Specific fruits and vegetables}

We observed inverse associations for apples and pears; oranges and tangerines; and orange and grapefruit juice (Table IV). After
(A) Total Fruit

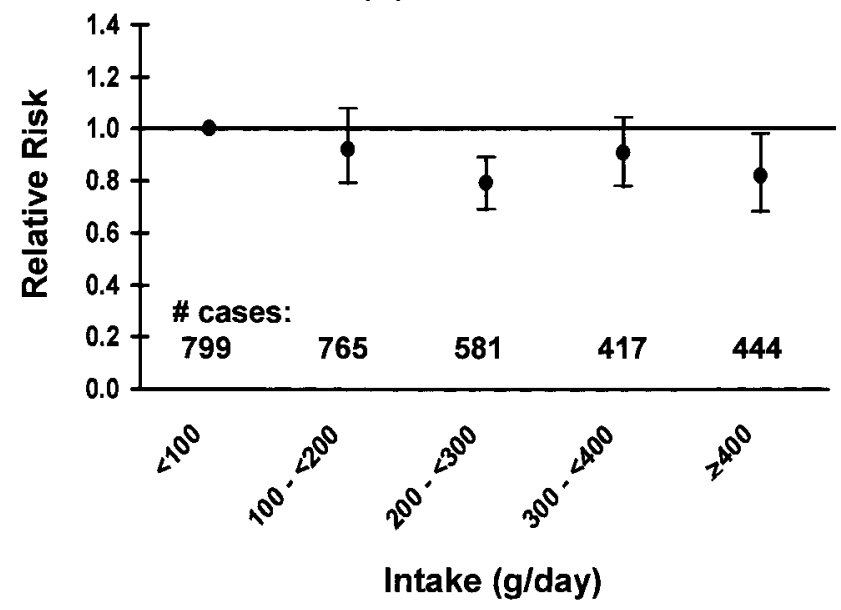

(B) Total Vegetables

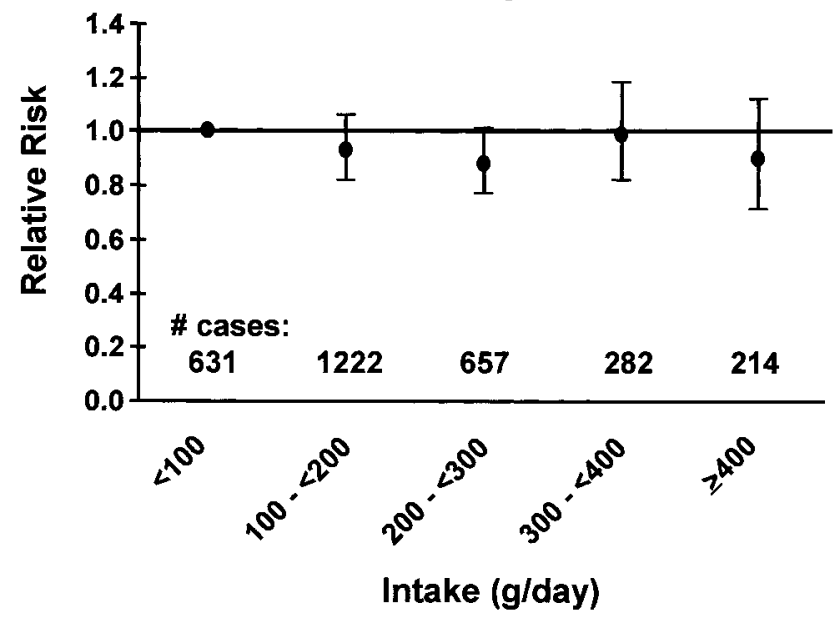

Figure 3 - Pooled multivariate relative risks and 95\% confidence intervals for lung cancer by categories of intake. In the total vegetable analyses, the Alpha-Tocopherol Beta-Carotene Cancer Prevention Study did not include any cases with vegetable intakes exceeding 400 g/day.

further adjustment for total fruit consumption, only the association for oranges and tangerines remained statistically significant (results not shown). None of the 9 specific vegetables examined was associated with the risk of lung cancer. Green leafy vegetable consumption (e.g., spinach, lettuce, mustard/collard greens, kale) was marginally significantly associated with lung cancer risk (pooled multivariate $\mathrm{RR}=0.93 ; 95 \% \mathrm{CI}=0.81-1.07$ comparing intakes of $\geq 1 / 2$ serving/day vs. $<1$ serving/week; $p$-value, test for trend $=0.07 ; p$-value, test for between-study heterogeneity $=$ $0.45)$.

\section{Evaluation of heterogeneity}

We analyzed whether associations of risk with total fruits, total vegetables and total fruits and vegetables differed by smoking status (Table V). For comparability across the smoking groups in these analyses, intakes were categorized into quartiles because the number of lung cancer cases among never smokers was limited. For total fruits, a nonsignificant $41 \%$ lower risk was observed among never smokers for comparisons of the highest vs. lowest quartile of consumption. Weaker associations were observed among current and past smokers but the differences between the 3 smoking strata were not statistically significant ( $p$-value, test for 
SMITH-WARNER ET AL.

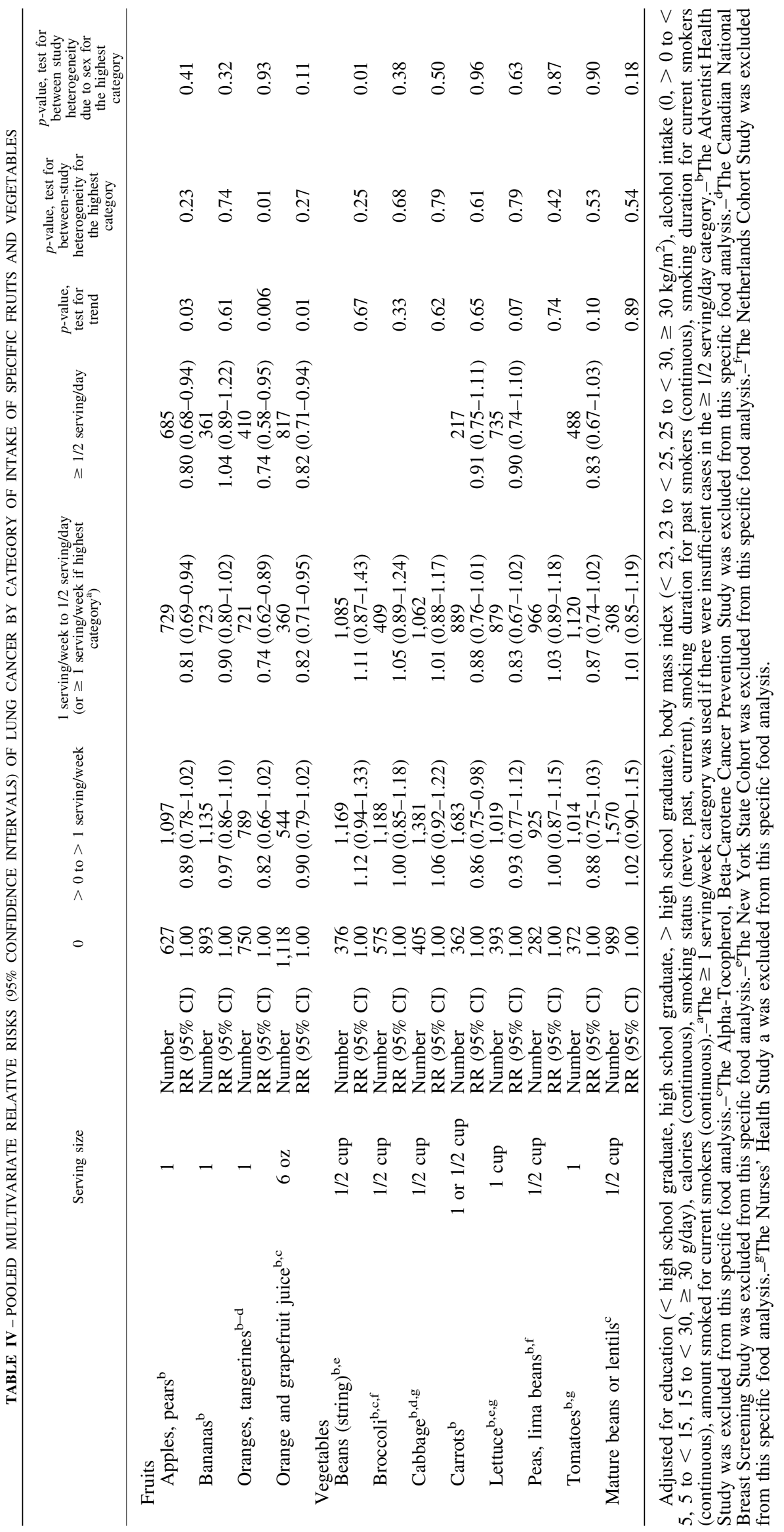


FRUITS, VEGETABLES AND LUNG CANCER

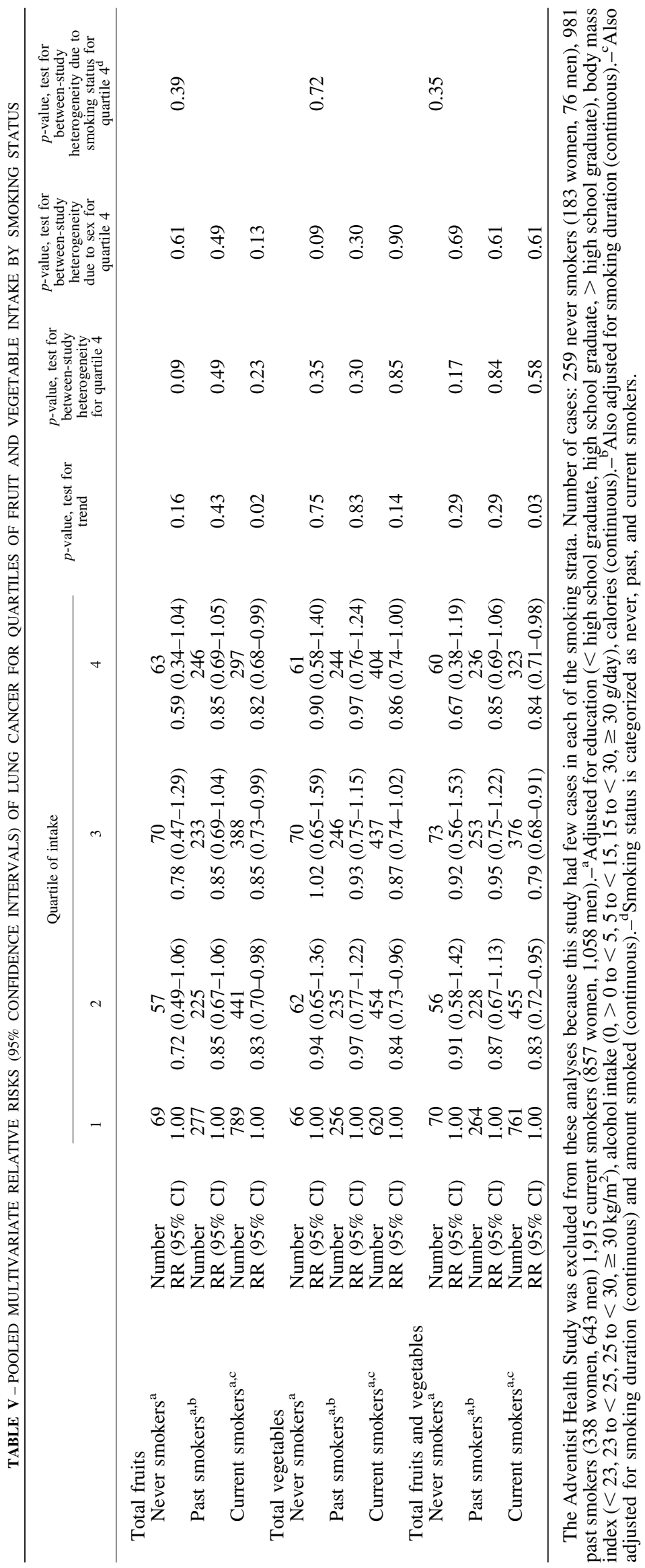


between-study heterogeneity due to smoking status $=0.39$ ). Vegetable consumption was inversely associated with lung cancer risk among current smokers but not among never or past smokers ( $p$-value, test for between-study heterogeneity due to smoking status $=0.72$ ).

We also evaluated associations by histologic type of lung cancer (Table VI). Although there was a suggestion of a stronger inverse association for adenocarcinomas and squamous cell carcinomas compared to small cell carcinomas for total fruit and total fruit and vegetable intakes, the differences between the 3 histologic types were not statistically significant ( $p$-value, test for common effects according to cell type for quartile $4=0.51$ for total fruits and 0.57 for total fruits and vegetables). Total vegetable consumption was not associated with any of the 3 histologic types and the results were not significantly different across the 3 types ( $p$-value, test for common effects according to cell type for quartile $4=0.63$ ).

\section{DISCUSSION}

We observed $29-56 \%$ lower risks of lung cancer among men and women with higher intakes of total fruits, total vegetables and total fruits and vegetables in age-adjusted analyses. These reductions in risk were greatly attenuated when we controlled for smoking. When adjusted for smoking status, the number of cigarettes smoked and the number of years smoked, the relative risks for these groups for quintiles 2 through 5 compared to the lowest quintile of consumption were similar to each other and, in analyses of women and men combined, did not exceed a $24 \%$ reduction in lung cancer risk. Statistically significant inverse associations were observed for apples and pears; oranges and tangerines; and orange and grapefruit juice. Sex, smoking status and the number of fruit and vegetable questions on the food frequency questionnaire did not significantly modify the association between fruit and vegetable intakes and lung cancer risk. There was consistency in the results for total fruits, total vegetables and total fruits and vegetables from the multiple subgroup analyses compared with the overall results.

We analyzed the association between fruit and vegetable consumption and lung cancer risk using categories based on quantiles and on identical absolute intake cutpoints across studies. With the study-specific quantile approach, true differences in population intakes are not taken into account, potentially resulting in misclassification of exposure. However, misclassification could also occur in the analyses based on identical absolute intake cutpoints because reported intakes of fruits and vegetables have been shown to increase with the number of fruit and vegetable items on a questionnaire, ${ }^{41}$ and there was a 5 -fold variation in the number of fruit and vegetable items on the questionnaires among the studies in this analysis. Consequently, between-study differences in estimates of fruit and vegetable consumption may be due to differences in questionnaire design and/or in true intakes. Despite the different potential for misclassification between these 2 analytic approaches, the inverse association between fruit and vegetable consumption and lung cancer risk was not linear and of similar magnitude for both approaches.

A recent summary 6 of 17 case-control and 7 cohort studies concluded that the evidence is convincing that elevated intakes of fruits, vegetables, green vegetables and carrots reduce lung cancer risk. Several case-control studies have shown at least a $25 \%$ reduction in lung cancer risk for comparisons of the highest vs. lowest intake category for fruits ${ }^{42-52}$ or vegetables. ${ }^{45-49,51,53-63}$ Other case-control studies have shown weaker or nonsignificant associations. ${ }^{44,50,52,54-58,60-71}$ Only a large case-control study among female nonsmokers reported a significant positive association for fruit consumption. ${ }^{72}$ For carrots and green leafy vegetables, reductions in lung cancer risk of $40-60 \%$ generally have been observed in case-control studies for comparisons of the highest vs. lowest intakes. ${ }^{42,43,45,47,49,51,52,55,59,62,63,65,73-81}$ However, in our analyses and among the cohort studies ${ }^{78-80,82-86}$ that

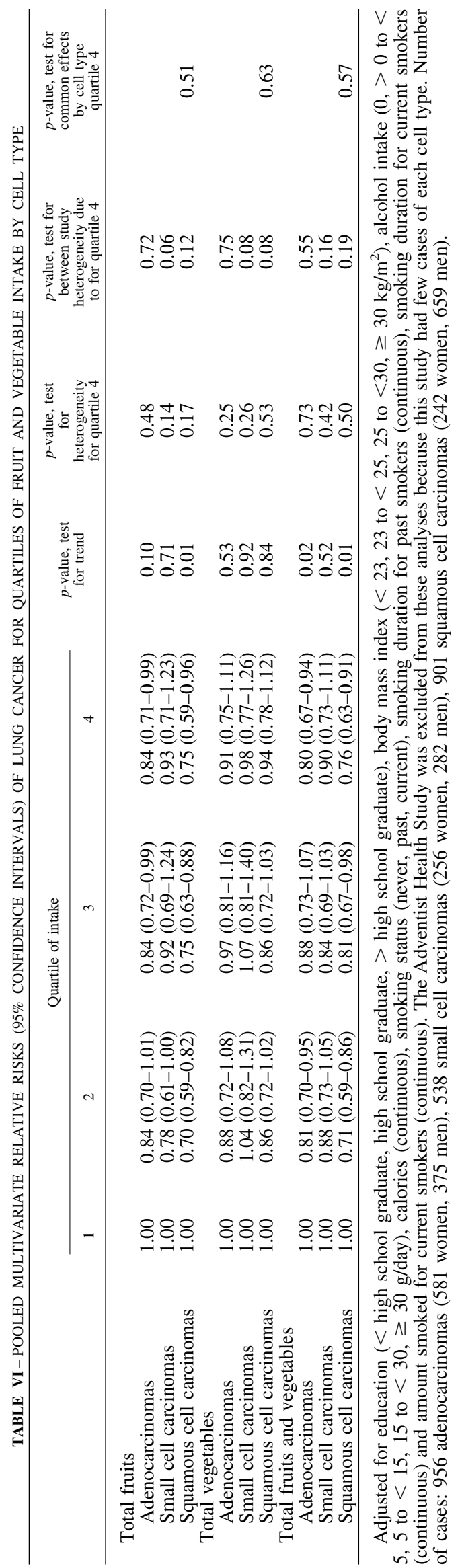


did not meet the criteria for inclusion in our study, weaker, and mostly nonsignificant, associations were observed for total vegetable, carrot and green leafy vegetable consumption. As in the case-control studies, an inverse association for total fruits was observed in our analyses, although nonsignificant associations have been observed in most, $78,79,82,86,87$ but not all, ${ }^{80,83}$ of the cohort studies not included in our analyses. We observed a nonlinear association for total fruits and vegetables and the risk of lung cancer that was increased only among those with the lowest intakes. These results suggest that even supplementation with the potentially biologically active compounds would have little effect in most persons, thus leading to a negative trial, as has been observed in some, ${ }^{88,89}$ but not all, ${ }^{90,91}$ clinical trials of beta-carotene supplementation.

Because smoking is strongly associated with lung cancer risk ${ }^{2-4}$ and smokers eat fewer fruits and vegetables compared to never smokers, ${ }^{92-97}$ differences in results across previous studies may be due in part to how smoking habits were controlled for in the multivariate models. Several studies have adjusted for smoking status only, ${ }^{46,55,82}$ which in our analyses was associated with incomplete control of confounding by smoking compared to models that also adjusted for smoking duration and dose. Differences in the degree of residual confounding by unmeasured smoking habits also may impact the strength of the associations observed.
For example, we were unable to control for smoking inhalation patterns, the type of cigarettes smoked, pipe and cigar smoking and environmental tobacco smoke because most cohorts did not collect this information. If these variables confound the association between fruit and vegetable consumption and lung cancer risk, then our results are likely to be overestimates of the true association. ${ }^{98,99}$ Arguing against residual confounding as the only explanation for the modest inverse association we observed for fruit consumption is the inverse association observed among never smokers.

In conclusion, we observed a modest nonlinear inverse association between fruit consumption and lung cancer risk with the highest risk limited to the lowest quintile of consumption. Little association was seen with vegetable intake. Because smoking is a strong risk factor for lung cancer ${ }^{2-4}$ and because for the studies in this analysis, current smokers had lower total fruit and, to a lesser degree, total vegetable intakes compared to never smokers, we cannot rule out the possibility that our results are due to residual confounding by smoking. However, even if no residual confounding is present, the modest inverse association observed for fruit intake, and the absence of a reduction with vegetable intake, reinforces the public health message that the primary focus for reducing lung cancer incidence and mortality should be on smoking prevention and cessation.

\section{REFERENCES}

1. Parkin DM, Bray F, Ferlay J, Pisani P. Estimating the world cancer burden: Globocan 2000. Int J Cancer 2001;94:153-6.

2. Chyou P-H, Nomura AMY, Stemmermann GN. A prospective study of the attributable risk of cancer due to cigarette smoking. Am J Public Health 1992;82:37-40.

3. Ernster VL. The epidemiology of lung cancer in women. Ann Epidemiol 1994:4:102-10.

4. Szabo E, Mulshine J. Epidemiology, prognostic factors, and prevention of lung cancer. Curr Opin Oncol 1993;5:302-9.

5. Ziegler RG, Mayne ST, Swanson CA. Nutrition and lung cancer. Cancer Causes Control 1996:7:157-77.

6. World Cancer Research Fund, American Institute for Cancer Research Expert Panel. Food, nutrition and the prevention of cancer: a global perspective. Washington, DC: American Institute for Cancer Research, 1997.

7. Smith-Warner SA, Giovannucci E. Fruit and vegetable intake and cancer. In: Heber D, Blackburn GL, Go VLW, eds. Nutritional oncology. Boston: Academic Press, 1999. 153-83.

8. Smith SA, Campbell DR, Elmer PJ, Martini MC, Slavin JL, Potter JD. The University of Minnesota Cancer Prevention Research Unit vegetable and fruit classification scheme (United States). Cancer Causes Control 1995;6:292-302.

9. Wattenberg LW. Inhibition of carcinogenesis by minor anutrient constituents of the diet. Proc Nutr Soc 1990;49:173-83.

10. Mangels AR, Holden JM, Beecher GR, Forman MR, Lanza E. Carotenoid content of fruits and vegetables: an evaluation of analytic data. J Am Diet Assoc 1993;93:284-96.

11. Steinmetz KA, Potter JD. Vegetables, fruit, and cancer: II, mechanisms. Cancer Causes Control 1991;2:427-42.

12. Hunter DJ, Spiegelman D, Adami H-O, Beeson L, van den Brandt PA, Folsom AR, et al. Cohort studies of fat intake and the risk of breast cancer: a pooled analysis. N Engl J Med 1996;334:356-61.

13. Feskanich D, Ziegler RG, Michaud DS, Giovannucci EL, Speizer FE, Willett WC, et al. Prospective study of fruit and vegetable consumption and risk of lung cancer among men and women. J Natl Cancer Inst 2000;92:1812-23.

14. Voorrips LE, Goldbohm RA, Verhoeven DTH, van Poppel GAFC, Sturmans F, Hermus RJJ, et al. Vegetable and fruit consumption and lung cancer risk in the Netherlands Cohort Study on Diet and Cancer. Cancer Causes Control 2000;11:101-15.

15. Steinmetz KA, Potter JD, Folsom AR. Vegetables, fruit, and lung cancer in the Iowa Women's Health Study. Cancer Res 1993;53:53643.

16. Fraser GE, Beeson WL, Phillips RL. Diet and lung cancer in California Seventh-Day Adventists. Am J Epidemiol 1991;133:683-93.

17. Albanes D, Heinonen OP, Taylor PR, Virtamo J, Edwards BK, Rautalahti $\mathrm{M}$, et al. $\alpha$-tocopherol and $\beta$-carotene supplements and lung cancer incidence in the $\alpha$-tocopherol, $\beta$-carotene cancer prevention study: effects of base-line characteristics and study compliance. J Natl Cancer Inst 1996;88:1560-70.

18. Bandera EV, Freudenheim JL, Marshall JR, Zielezny M, Priore RL,
Brasure J, et al. Diet and alcohol consumption and lung cancer risk in the New York State Cohort (United States). Cancer Causes Control 1997;8:828-40.

19. Rohan TE, Jain M, Howe GR, Miller AB. A cohort study of dietary carotenoids and lung cancer risk in women (Canada). Cancer Causes Control 2002:13:231-7.

20. Rothman KJ. Modern epidemiology. Boston: Little, Brown, 1986.

21. Pennington JAT. Bowes and Church's food values of portions commonly used, 17th ed. New York: Lippincott-Raven, 1998.

22. Abbey DE, Andress M. Fraser G, Morgan J. Validity and reliability of alternative nutrient indices based on a food frequency questionnaire. Am J Epidemiol 1988;128:934.

23. Pietinen $\mathrm{P}$, Hartman AM, Haapa E, Räsänen L, Haapakoski J, Palmgren J, et al. Reproducibility and validity of dietary assessment instruments: I, a self-administered food use questionnaire with a portion size picture booklet. Am J Epidemiol 1988;128:655-66.

24. Jain M, Howe GR, Rohan T. Dietary assessment in epidemiology: comparison of a food frequency and a diet history questionnaire with a 7-day food record. Am J Epidemiol 1996;143:953-60.

25. Rimm EB, Giovannucci EL, Stampfer MJ, Colditz GA, Litin LB, Willett WC. Reproducibility and validity of an expanded self-administered semiquantitative food frequency questionnaire among male health professionals. Am J Epidemiol 1992;135:1114-26.

26. Munger RG, Folsom AR, Kushi LH, Kaye SA, Sellers TA. Dietary assessment of older Iowa women with a food frequency questionnaire: nutrient intake, reproducibility, and comparison with 24-hour dietary recall interviews. Am J Epidemiol 1992;136:192-200.

27. Goldbohm RA, van den Brandt PA, Brants HAM, van't Veer P, Al M, Sturmans F, et al. Validation of a dietary questionnaire used in a large-scale prospective cohort study on diet and cancer. Eur J Clin Nutr 1994:48:253-65

28. Feskanich D, Marshall J, Rimm EB, Litin LB, Willett WC. Simulated validation of a brief food frequency questionnaire. Ann Epidemiol 1994:4:181-7.

29. Willett WC, Sampson L, Stampfer MJ, Rosner B, Bain C, Witschi J, et al. Reproducibility and validity of a semiquantitative food frequency questionnaire. Am J Epidemiol 1985;122:51-65.

30. Salvini S, Hunter DJ, Sampson L, Stampfer MJ, Colditz GA, Rosner $\mathrm{B}$, et al. Food-based validation of a dietary questionnaire: the effects of week-to-week variation in food consumption. Int $\mathrm{J}$ Epidemiol 1989:18:858-67.

31. Feskanich D, Rimm EB, Giovannucci EL, Colditz GA, Stampfer MJ, Litin LB, et al. Reproducibility and validity of food intake measurements from a semiquantitative food frequency questionnaire. J Am Diet Assoc 1993;93:790-6.

32. ATBC Cancer Prevention Study Group. The Alpha-Tocopherol, BetaCarotene Lung Cancer Prevention Study: design, methods, participant characteristics, and compliance. Ann Epidemiol 1994;4:1-10.

33. Percy C, Van Holten V, Muir C, International classification of diseases for oncology. Geneva: World Health Organization, 1990. 
34. Prentice RL. A case-cohort design for epidemiologic cohort studies and disease prevention trials. Biometrika 1986;73:1-11.

35. EPICURE user's guide. The PEANUTS program. Seattle: Hirosoft, 1993.

36. SAS/STAT software. The PHREG procedure: preliminary documentation. Cary: SAS Institute, 1991.

37. DerSimonian R, Laird N. Meta-analysis in clinical trials. Control Clin Trials 1986;7:177-88.

38. Cochran WG. The combination of estimates from different experiments. Biometrics 1954;10:101-29.

39. Stram DO. Meta-analysis of published data using a linear mixedeffects model. Biometrics 1996;52:536-44.

40. Prentice RL, Kalbfleisch JD, Peterson AV, Flavnoy N, Farewell YT, Breslow NE. The analysis of failure times in the presence of competing risks. Biometrics 1978;34:541-54.

41. Krebs-Smith SM, Heimendinger J, Subar AF, Patterson BH, Pivonka E. Using food frequency questionnaires to estimate fruit and vegetable intake: association between the number of questions and total intakes. J Nutr Edu 1995;27:80-5.

42. Fontham ETH, Pickle LW, Haenszel W, Correa P, Lin Y, Falk RT. Dietary vitamins A and $\mathrm{C}$ and lung cancer risk in Louisiana. Cancer $1988 ; 62: 2267-73$

43. Koo LC. Dietary habits and lung cancer risk among Chinese females in Hong Kong who never smoked. Nutr Cancer 1988;11:155-72.

44. Kalandidi A, Katsouyanni K, Voropoulou N, Bastas G, Saracci R, Trichopoulos D. Passive smoking and diet in the etiology of lung cancer among non-smokers. Cancer Causes Control 1990;1:15-21.

45. Candelora EC, Stockwell HG, Armstrong AW, Pinkham PA. Dietary intake and risk of lung cancer in women who never smoked. Nutr Cancer 1992;17:263-70.

46. Gao C-M, Tajima K, Kuroishi T, Hirose K, Inoue M. Protective effects of raw vegetables and fruit against lung cancer among smokers and ex-smokers: a case-control study in the Tokai Area of Japan. Jpn J Cancer Res 1993;84:594-600.

47. Axelsson G, Liljeqvist T, Andersson L, Bergman B, Rylander R. Dietary factors and lung cancer among men in West Sweden. Int $\mathbf{J}$ Epidemiol 1996;25:32-9.

48. Lei Y-X, Cai W-C, Chen Y-Z, Du Y-X. Some lifestyle factors in human lung cancer: a case-control study of 792 lung cancer cases. Lung Cancer 1996;14(Suppl):S121-36.

49. Pawlega J, Rachtan J, Dyba T. Evaluation of certain risk factors for lung cancer in Cracow (Poland). Acta Oncol 1997;36:471-6.

50. Pillow PC, Hursting SD, Duphorne CM, Jiang H, Honn SE, Chang S, et al. Case-control assessment of diet and lung cancer risk in African Americans and Mexican Americans. Nutr Cancer 1997;29:169-73.

51. De Stefani E, Boffetta P, Deneo-Pellegrini H, Mendilaharsu M, Carzoglio JC, Ronco A, et al. Dietary antioxidants and lung cancer risk: a case-control study in Uruguay. Nutr Cancer 1999;34:100-10.

52. Marchand JL, Luce D, Goldberg P, Bugel I, Salomon C, Goldberg M. Dietary factors and the risk of lung cancer in New Caledonia (South Pacific). Nutr Cancer 2002;42:18-24.

53. MacLennan R, Da Costa J, Day NE, Law CH, Ng YK, Shanmugaratnam K. Risk factors for lung cancer in Singapore Chinese, a population with high female incidence rates. Int J Cancer 1977;20: 854-60.

54. Ziegler RG, Mason TJ, Stemhagen A, Hoover R, Schoenberg JB, Gridley $\mathrm{G}$, et al. Carotenoid intake, vegetables, and the risk of lung cancer among white men in New Jersey. Am J Epidemiol 1986;123: $1080-93$.

55. Le Marchand L, Yoshizawa CN, Kolonel LN, Hankin JH, Goodman MT. Vegetable consumption and lung cancer risk: a population-based case-control study in Hawaii. J Natl Cancer Inst 1989;81:1158-64.

56. Jain M, Burch JD, Howe GR, Risch HA, Miller AB. Dietary factors and risk of lung cancer: results from a case-control study, Toronto, 1981-1985. Int J Cancer 1990;45:287-93.

57. Forman MR, Yao SX, Graubard BI, Qiao YL, McAdams M, Mao BL, et al. The effect of dietary intake of fruits and vegetables on the odds ratio of lung cancer among Yunnan tin miners. Int $\mathrm{J}$ Epidemiol 1992;21:437-41.

58. Mayne ST, Janerich DT, Greenwald P, Chorost S, Tucci C, Zaman $\mathrm{MB}$, et al. Dietary beta carotene and lung cancer risk in U.S. nonsmokers. J Natl Cancer Inst 1994:86:33-8.

59. Sankaranarayanan R, Varghese C, Duffy SW, Padmakumary G, Day NE, Nair MK. A case-control study of diet and lung cancer in Kerala, South India. Int J Cancer 1994;58:644-9.

60. Agudo A, Esteve MG, Pallarés C, Martínez-Ballarín I, Fabregat X, Malats N, et al. Vegetable and fruit intake and the risk of lung cancer in women in Barcelona, Spain. Eur J Cancer 1997;33:1256-61.

61. Ko Y-C, Lee C-H, Chen M-J, Huang C-C, Chang W-Y, Lin H-J, et al. Risk factors for primary lung cancer among non-smoking women in Taiwan. Int J Epidemiol 1997;26:24-31.

62. Nyberg F, Agrenius V, Svartengren K, Svensson C, Pershagen G.
Dietary factors and risk of lung cancer in never-smokers. Int J Cancer 1998;78:430-6.

63. Brennan P, Fortes C, Butler J, Agudo A, Benhamou S, Darby S, et al. A multicenter case-control study of diet and lung cancer among non-smokers. Cancer Causes Control 2000;11:49-58.

64. Pierce RJ, Kune GA, Kune S, Watson LF, Field B, Merenstein D, et al. Dietary and alcohol intake, smoking pattern, occupational risk, and family history in lung cancer patients: results of a case-control study in males. Nutr Cancer 1989;12:237-48.

65. Mohr DL, Blot WJ, Tousey PM, Van Doren ML, Wolfe KW. Southern cooking and lung cancer. Nutr Cancer 1999;35:34-43.

66. Swanson CA, Mao BL, Li JY, Lubin JH, Yao SX, Wang JZ, et al Dietary determinants of lung-cancer risk: results from a case-control study in Yunnan Province, China. Int J Cancer 1992;50:876-80.

67. Swanson CA, Brown CC, Sinha R, Kulldorff M, Brownson RC, Alavanja MCR. Dietary fats and lung cancer risk among women: the Missouri Women's Health Study (United States). Cancer Causes Control 1997;8:883-93.

68. Hu J, Johnson KC, Mao Y, Xu T, Lin Q, Wang C, et al. A case-control study of diet and lung cancer in Northeast China. Int J Cancer 1997;71:924-31.

69. Alavanja MCR, Brown CC, Swanson C, Brownson RC. Saturated fat intake and lung cancer risk among nonsmoking women in Missouri. J Natl Cancer Inst 1993;85:1906-16.

70. Wright ME, Mayne ST, Swanson CA, Sinha R, Alavanja MCR. Dietary carotenoids, vegetables, and lung cancer risk in women: the Missouri Women's Health Study (United States). Cancer Causes Control 2003;14:85-96.

71. Kubík A, Zatloukal P, Tomášek L, Kríž J, Petruželka L, Pleško I. Diet and the risk of lung cancer among women. A hospital-based casecontrol study. Neoplasma 2001;48:262-6.

72. Wu-Williams AH, Dai XD, Blot W, Xu ZY, Sun XW, Xiao HP, et al. Lung cancer among women in north-east China. Br J Cancer 1990; 62:982-7.

73. Mettlin C, Graham S, Swanson M. Vitamin A and lung cancer. J Natl Cancer Inst 1979;62:1435-8.

74. Pisani P, Berrino F, Macaluso M, Pastorino U, Crosignani P, Baldasseroni A. Carrots, green vegetables and lung cancer: a case-control study. Int J Epidemiol 1986;15:463-8.

75. Harris RWC, Key TJA, Silcocks PB, Bull D, Wald NJ. A case-control study of dietary carotene in men with lung cancer and in men with other epithelial cancers. Nutr Cancer 1991;15:63-8.

76. Mettlin C. Milk drinking, other beverage habits, and lung cancer risk. Int J Cancer 1989;43:608-12.

77. Bond GG, Thompson FE, Cook RR. Dietary vitamin A and lung cancer: results of a case-control study among chemical workers. Nutr Cancer 1987;9:109-21.

78. Chow W-H, Schuman LM, McLaughlin JK, Bjelke E, Gridley G, Wacholder S, et al. A cohort study of tobacco use, diet, occupation, and lung cancer mortality. Cancer Causes Control 1992;3:247-54.

79. Kvåle G, Bjelke E, Gart JJ. Dietary habits and lung cancer risk. Int J Cancer 1983;31:397-405.

80. Knekt P, Järvinen R, Teppo L, Aromaa A, Seppänen R. Role of various carotenoids in lung cancer prevention. J Natl Cancer Inst 1999;91:182-4.

81. Rachtan J. Dietary habits and lung cancer risk among Polish women. Acta Oncol 2002;41:389-94

82. Shibata A, Paganini-Hill A, Ross RK, Henderson BE. Intake of vegetables, fruits, beta-carotene, vitamin $\mathrm{C}$ and vitamin supplements and cancer incidence among the elderly: a prospective study. $\mathrm{Br} \mathrm{J}$ Cancer 1992;66:673-9.

83. Ocké MC, Bueno-de-Mesquita HB, Feskens EJM, van Staveren WA, Kromhout D. Repeated measurements of vegetables, fruits, $\beta$-carotene, and vitamins $\mathrm{C}$ and $\mathrm{E}$ in relation to lung cancer: the Zutphen study. Am J Epidemiol 1997;145:358-65.

84. Breslow RA, Graubard BI, Sinha R, Subar AF. Diet and lung cancer mortality: a 1987 National Health Interview Survey cohort study. Cancer Causes Control 2000;11:419-31.

85. Neuhouser ML, Patterson RE, Thornquist MD, Omenn GS, King IB, Goodman GE. Fruits and vegetables are associated with lower lung cancer risk only in the placebo arm of the $\beta$-carotene and retinol efficacy trial (CARET). Cancer Epidemiol Biomarkers Prev 2003;12: $350-8$.

86. Jansen MC, Bueno-de-Mesquita HB, Räsänen L, Fidanza F, Nissinen AM, Menotti A, et al. Cohort analysis of fruit and vegetable consumption and lung cancer mortality in European men. Int $\mathrm{J}$ Cancer 2001;92:913-8.

87. Key TJA, Thorogood M, Appleby PN, Burr ML. Dietary habits and mortality in 11,000 vegetarians and health conscious people: results of a 17 year follow up. Br Med J 1996;313:775-9.

88. Hennekens CH, Buring JE, Manson JE, Stampfer M, Rosner B, Cook $\mathrm{NR}$, et al. Lack of effect of long-term supplementation with beta 
carotene on the incidence of malignant neoplasms and cardiovascular disease. N Engl J Med 1996;334:1145-9.

89. Lee IM, Cook NR, Manson JE, Buring JE, Hennekens CH. $\beta$-carotene supplementation and incidence of cancer and cardiovascular disease: the Women's Health Study. J Natl Cancer Inst 1999;91:2102-6.

90. The Alpha-Tocopherol Beta Carotene Cancer Prevention Study Group. The effect of vitamin $\mathrm{E}$ and beta carotene on the incidence of lung cancer and other cancers in male smokers. $\mathrm{N}$ Engl J Med 1994;330:1029-35.

91. Omenn GS, Goodman GE, Thornquist MD, Balmes J, Cullen MR, Glass A, et al. Effects of a combination of beta carotene and vitamin A on lung cancer and cardiovascular disease. N Engl J Med 1996; 334:1150-5.

92. Serdula MK, Byers T, Mokdad AH, Simoes E, Mendlein JM, Coates RJ. The association between fruit and vegetable intake and chronic disease risk factors. Epidemiology 1996;7:161-5.

93. Giraud DW, Martin HD, Driskell JA. Plasma and dietary vitamin C and E levels of tobacco chewers, smokers, and nonusers. J Am Diet Assoc 1995;95:798-800.

94. Subar AF, Harlan LC, Mattson ME. Food and nutrient intake differ- ences between smokers and non-smokers in the US. Am J Public Health 1990;80:1323-9.

95. McPhillips JB, Eaton CB, Gans KM, Derby CA, Lasater TM, McKenney JL, et al. Dietary differences in smokers and nonsmokers from two southeastern New England communities. J Am Diet Assoc 1994;94:287-92.

96. Thornton A, Lee P, Fry J. Differences between smokers, ex-smokers, passive smokers and non-smokers. J Clin Epidemiol 1994;47:114362.

97. Nuttens MC, Romon M, Ruidavets JB, Arveiler D, Ducimetiere P, Lecerf JM, et al. Relationship between smoking and diet: the MONICA-France project. J Intern Med 1992;231:349-56.

98. Marshall JR, Hastrup JL, Ross JS. Mismeasurement and the resonance of strong confounders: correlated errors. Am J Epidemiol 1999;150: $88-96$.

99. Stram DO, Huberman M, Wu AH. Is residual confounding a possible explanation for the apparent protective effects of beta-carotene found in epidemiological studies of lung cancer in smokers? Am J Epidemiol 2002; 155:622-8. 